\title{
Globalizations
}

\section{‘Our world was made by nature': constructions of spontaneous order}

\section{Gareth Dale}

To cite this article: Gareth Dale (2018) 'Our world was made by nature': constructions of spontaneous order, Globalizations, 15:7, 924-940, DOI: 10.1080/14747731.2018.1498172

To link to this article: https://doi.org/10.1080/14747731.2018.1498172
(c) 2018 The Author(s). Published by Informa UK Limited, trading as Taylor \& Francis Group

\section{里 Published online: 24 Jul 2018.}

Submit your article to this journal $\widetilde{ }$

Џll Article views: 1484

Q View related articles $\longleftarrow$

View Crossmark data $\nearrow$ 


\title{
'Our world was made by nature': constructions of spontaneous order
}

\author{
Gareth Dale \\ Politics and History, Brunel University London, Uxbridge, Middlesex, UK
}

\begin{abstract}
This article explores the concepts of spontaneity and spontaneous order, in particular their deployment by Friedrich Hayek and Karl Polanyi. Although in many respects these thinkers were poles apart, the article identifies a point of convergence. They both mobilize the concept of spontaneity in a manner that naturalizes a particular social process: for Hayek, the market economy, for Polanyi, society's protective movement that arises in reaction against the market economy. To contextualize the uses of spontaneity by Hayek and Polanyi, I trace its evolution, with reference to Leibniz, Mandeville, and the thinkers of the Scottish Enlightenment. Having sketched the ways in which earlier thinkers understood spontaneity, I turn finally to Hayek and Polanyi. I argue that their invocations of spontaneity and spontaneous order contribute to a downplaying of relations of domination and exploitation. While Hayek sees the market system as the exemplar of spontaneous order, for Polanyi, the concept of spontaneity underpins his belief that the protective countermovement is a 'natural' reaction to the evils of market society; as such, power relations pass beneath the radar.
\end{abstract}

\section{KEYWORDS}

Karl Polanyi; Friedrich Hayek; spontaneity; spontaneous order; Michael Polanyi

This article attempts a critical investigation of spontaneity and spontaneous order, concepts that have long played a role in social thought, and in particular their deployment in the work of Friedrich Hayek and Karl Polanyi. Although in most respects these two thinkers were poles apart, I identify one point of convergence. They both mobilize the concept of spontaneity in a manner that naturalizes a particular social arrangement: for Hayek, the market economy, for Polanyi, society's movement of social protection that arises in reaction against the market economy.

To understand the meaning of spontaneity in Hayek and Polanyi's work, I trace its development in earlier social theory, with reference to Leibniz, whose use of spontaneity aligns it with the lack of coercion, to Mandeville and thence to the thinkers of the Scottish Enlightenment, from whom Hayek took inspiration. While Hayek constructs the idea of spontaneous order as a clear-cut tradition, advanced by Hume, Smith and Ferguson much as by Hayek himself, I explore aspects of their interpretations that jar with his. I then turn briefly to the nineteenth-century sociologist Herbert Spencer, whose conception of spontaneous order is rather closer to Hayek's in its integration of themes from Darwinian evolutionary theory, but also in its crude dichotomy of 'militant' and 'industrial' forms of society.

Having sketched the ways in which earlier thinkers understood spontaneity, I turn finally to Hayek and Polanyi. I argue that their invocations of spontaneity and spontaneous order contribute

CONTACT Gareth Dale gareth.dale@brunel.ac.uk

(c) 2018 The Author(s). Published by Informa UK Limited, trading as Taylor \& Francis Group

This is an Open Access article distributed under the terms of the Creative Commons Attribution-NonCommercial-NoDerivatives License (http:// creativecommons.org/licenses/by-nc-nd/4.0/), which permits non-commercial re-use, distribution, and reproduction in any medium, provided the original work is properly cited, and is not altered, transformed, or built upon in any way. 
to an underplaying of relations of domination and exploitation - in Hayek's case egregiously, in Polanyi's case subtly. In Hayek, this occurs through the antithesis he establishes between freedom and coercion, with the former associated strongly with markets and the latter with states, and through his defence of social inequality in capitalist society as indispensable to spontaneous social progress. In Polanyi, it occurs through his acceptance of some key liberal ideas on the spontaneous self-ordering tendencies of the market system, and his downplaying of exploitation in statist economies. In both cases, the concept of spontaneity is a contributory factor. Hayek sees the market system as the exemplar of spontaneous order, one that allows individuals to freely find their role. For Polanyi, the concept of spontaneity underpins his belief that the protective countermovement is a 'natural' reaction to the evils of market society; as such, power relations pass beneath the radar.

\section{'Lawfulness without a law'}

In several areas of social and economic theory, including studies of social movements and of market order, 'spontaneity' figures prominently. It is a concept that matters. But it is frustratingly - or intriguingly - rubbery. It gathers connotations of free will, naturalness, self-generation, and randomness. Its ambiguities are as striking as its associations are heterogenous (immediacy, nature, the 'genuine' self). Is spontaneous activity unforced, unintended or undetermined? Is it unpredictable yet law-governed? When applied to human beings, does spontaneity refer to sincerity and authenticity (the consonance between one's words and feelings, between head and heart), or to acts in which conscious deliberation is absent, or to expressions of unconstrained autonomy, or somehow to all of these? When referring to willed behaviour, does it denote something unconscious (especially if habitual or contagious), or behaviour that is intentional but yielding of unintended consequences?

Concepts with similar profiles to spontaneity, and even 'spontaneous order,' go back a long way. In the fourth century BC the Chinese philosopher Zhuang Zhou observed that 'good order results spontaneously when things are let alone' (Hamoway, 1987, p. 6). Several centuries later the Epicurean philosopher Lucretius penned De Rerum Natura (The Nature of Things) which contains the following lines:

Our world was made by nature, when

atoms, meeting by chance, spontaneously,

and joined in myriad useless, fruitless ways,

at last found patterns, which when thrown together

became at once the origin of great things -

earth, sea, and sky, and life in all its forms.

In Europe, 'spontaneous' was in use from the thirteenth century, to refer to people acting of their own accord, but it did not enter common usage until the 1650s. It was not always positively freighted, yet its increased popularity was striking. What were its causes? And why did the breakthrough occur in the mid-seventeenth century? At least in England, a transformation in religious subjectivity played a part. In the theological flux of the revolutionary decades, Protestants, including some Puritans and many other Dissenters, downgraded liturgy or even castigated it as sinful. This of course did not open them to an embrace of spontaneity as a general principle of behaviour. Puritanism instilled a rigid order into the conduct of its adherents through educating them to a continuous self-monitoring and detailed control of their lives, and to the repression of libido - 'the destruction of spontaneous, impulsive enjoyment,' in Max Weber's description (1905/1992, pp. 119-126). But within 
the compass of the believer-deity relationship the new emphasis was on its sincerity, performed and affirmed through spontaneous prayer and other forms of 'enthusiastic' worship. Lori Branch (2009, p. 4) refers to this as the new 'spirituality of spontaneity, with its ethos of free prayer, emotional selfscrutiny, and evangelism.' Spontaneous emotional effusion came to be understood 'as evidence of the condition of one's heart, when that heart came to be conceived of as an object of investigation, appraisal, and exchange like so many others in the given world.' It is best interpreted, she suggests (2009, p. 87), as the product of the era's transformed epistemological and economic discourses, and also as 'a constellation of resistances borne of this subjection.'

The same era also witnessed a burgeoning interest in what would later become known as spontaneous order. The demotion of the deity from an executive to a merely legislative role, from puppet master to instruction-manual author, against a backdrop of wrenching social change and political tumult, all this called for new ways of conceptualizing social order: its foundations, dynamics and complexity. In an earlier age, for example that of Calvin, providence had been a moral doctrine: the belief that God is at work in the world. Faith, not knowledge, was its object (Sheehan \& Wahrman, 2015, p. 18). But in the mid-seventeenth century, philosophers such as Gassendi blended the theological concept of providence together with Lucretian materialism to confect a providential naturalism. In this view, God had created atoms, infusing them with energy and a tendency to order (Sheehan \& Wahrman, 2015, p. 30). So conceived, providence was the key to understanding the universe; it was now an epistemological and ontological doctrine, not merely a moral one. Moreover, philosophers reasoned, the Bible teaches that God commanded the ground to bring forth plants and living creatures, perhaps, therefore, God's blueprint for creation still existed in matter such that, in the right conditions, new life could be spontaneously produced. This idea underpinned, also in the 1650s, a renaissance, now in Christian colours, of the ancient doctrine of the spontaneous generation of life from inanimate matter. In London, the illuminati of the Royal Society attempted to prove the spontaneous generation of life by showing the 'creation' of insects from cheese (Ginzburg, 1976, p. 57; Ziman, 1991, p. 57).

The new language of spontaneous sentiments, Branch suggests, jibed with 'the languages of experimental discovery and with mercantile and emerging consumer discourses of being current and upto-date,' in comparison with which the old practices of ritual and repetition appeared as superstitious, authoritarian and out-of-date, smothering of 'the natural responses of the soul' (Branch, 2009 , p. 4). One type of ascendant discourse was associated with the revolution in the sciences notably, the belief that the natural world is governed by Newtonian principles, with order emerging spontaneously from the interaction of nature's myriad corpuscles. Another was the concern for individual autonomy and self-determination, and it, in turn, connected to the new paradigm of market and contract. Whereas the market, as it had operated in earlier centuries was, in Foucault's words (Foucault, 2008, p. 30), 'essentially a site of justice,' by the mid-seventeenth century it was coming to be regarded as "something that obeyed and had to obey "natural," that is to say, spontaneous mechanisms.' In comparison with previous forms of absolutism, Terry Eagleton suggests (1990, p. 27), a shift occurred in the balance between coercion and consent: where individuals in their economic lives required a substantial degree of autonomy, power, to be effective, had to be inscribed in the minutiae of subjective experience.' In the nascent bourgeois order, individuals found themselves isolated and rivalrous in their economic existence; at the political level they appeared to be connected by little but abstract rights. This is why the realm of pieties, intuitions, sentiments, affections and 'spontaneous bodily habits' gained such importance: to it fell the task of cohering 'an otherwise abstract, atomized order.' The individual authentication of power in the new order required the construction, within the subject, of 'a new form of inwardness,' one that would perform 'the unpalatable 
work of the law.' Law, then, could in effect dissolve into custom and habit, such that 'to transgress that law would signify a deep self-violation' (Eagleton, 1990, p. 20). Philosophers began to speak of 'lawfulness without a law' (Kant) and 'authority which is not an authority' (Rousseau), as ways of envisaging a new kind of universal law, one that 'lives wholly in its free, individual incarnations,' the law being ultimately nothing but 'an assembly of autonomous self-governing particulars working in spontaneous reciprocal harmony' (Eagleton, 1990, p. 21).

The embedding of the idea (or ideology) of spontaneity within a broader and increasingly secular culture was a task, first and foremost, for philosophy (Branch, 2009, p. 89). In Britain, the pioneers were moral philosophers: the Earl of Shaftesbury, who knitted the ethos of spontaneous benevolence and spontaneous 'natural affection' together with those of gentility, emotional sincerity and moral sensitivity (Branch, 2009, p. 3, 10), and the Scottish moralists, on whom more below. In Germany, the same period saw spontaneity receive sustained scrutiny from Gottfried Leibniz. In his writings, spontaneity is positioned in immediate proximity to self-determination, and therewith close to the Enlightenment grail: the perfection of all things and all humans. The natural changes to which each monad is subject, Leibniz proposed (in Sgarbi, 2012), 'come from an internal principle,' and the more that substances 'are determined by themselves, ... the more perfect they are' (Leibnitz, 1692/2010, p. 94). Human freedom, in his definition, is the 'spontaneity of someone endowed with intellect,' with spontaneity itself defined as 'contingency without coercion' (Leibnitz, 1692/2010, p. 94). Leibniz attempted, further, to categorize spontaneity into subgroups: willed and involuntary, for example. 'Everything voluntary is spontaneous,' he reasoned (in Losonsky, 2001, p. 174), 'but there are spontaneous actions which are not chosen and therefore are not voluntary' - a ball set in motion would be a case in point. Kant was later to elaborate on Leibniz' taxonomy. He differentiated among different types of spontaneity, including 'absolute,' 'relative,' and 'automatic.' (The latter is seen 'when a machine moves itself according to an inner principle, e.g. a watch' (Kant, in Sgarbi, 2012, p. 76)). And, like Leibniz before him, Kant aligned spontaneity with the idea of the essential self-activity of the subject, or self-determination - a move that was taken up by the idealist philosophers Fichte, Schelling and Hegel; they steered it toward a new, Romantic philosophy of subjectivity.

\section{After the bubble}

In its broad-brush summary of a centuries-long set of developments, the above survey may give the impression that developments followed one another smoothly and logically. But they did not. There were multiple non-synchronicities and contradictions. Not the least of these was that the age was punctuated with wars, revolutions, social tumult and economic crisis, even as the dominant Cartesian philosophy was depicting the universe as governed by regular and mechanistic laws - this was the period in which God was first imagined as the divine watchmaker (Durant \& Durant, 1963, p. 618).

It is a contradiction that has piqued the interest of two historians of early modern Europe, Jonathan Sheehan and Dror Wahrman. In Invisible Hands, they trace the novel conceptualizations of the law-governed character of human society that grew from the dissatisfaction with the simplicity and predictability of the Cartesian universe. A seminal decade was the 1720 s. It was then, particularly in Britain, that self-organization, in the sense of reflection on the existence of forms of order beyond the worldview both of the mechanical philosophers and traditional providence, emerged as a recognizable cultural phenomenon. The world, as it was now envisaged, was 'vulnerable to the operations of chance,' because not manipulated in detail by a divine architect, but it nonetheless appeared to be 'organized by unseen and powerful forces.' Imagining this algebra of social order 'required new 
appreciations for complexity, new understandings of causality, and new functions for the divine hand.' In response to the question of what did guarantee order, contemporaries came up with a novel notion: that, when left to their own devices, complex systems generate order immanently, without external direction, through self-organization (Sheehan \& Wahrman, 2015, p. x).

Why was it specifically the 1720s that saw the emergence of this new concept - of complex selforganizing social patterns ('order') arising as the unanticipated outcome of unconnected, random, atomic acts? The precipitating cause, Sheehan and Wahrman suggest, were the Mississippi and South Sea financial bubbles of 1719-1720 and their aftermath. This thesis is speculative, but Invisible Hands brings together an array of evidence in its support. The argument begins with the bubbles. These bouts of financial hyperactivity and hyperinflation provoked within Britain's upper echelons an obsessive interest, and an unsettling sense of disorder (Sheehan \& Wahrman, 2015, p. 99). When a bubble bursts, a contemporary explained, it brings

a prodigious Number of Sellers to the Market, one Man selling alarms another, and makes him sell, and thus the Stock has run down insensibly, till all the People are put in a Fright; and such has been the panick Fear, that it has brought great Confusion along with it. (Sheehan \& Wahrman, 2015, p. 106)

A bubble brings chaos, suddenly and very visibly. But in each case order swiftly returned - and at least in Britain's experience of the South Sea Bubble, even its deflation exerted only a small impact on bankruptcy levels (Knafo, 2013, p. 116).

These periods, of ferment and turbulence followed by a rapid return to order, inspired a growing doubt in the sufficiency of inherited models of causality. The vision of Newtonian order - that consequences follow causes in linear and stable fashion - was disrupted. Regularity crumbled into chance. Was each bubble caused by Providence? Was it conspiracy? Some contemporaries explained it away in these terms. Others identified Whiggish over-ambition as the culprit. (The Tory propagandist Daniel Defoe, for example, charged John Law, chief architect of the Mississippi Bubble, with having

screw'd up the adventurous Humour of the People by starting every Day new Surprizes, new Oceans for them to launch out into; so supporting one Chimera by another, building Infinite upon Infinite, which it was evident must sink all at last into infinite Confusion. (in Wennerlind, 2011, p. 237))

Still others, however, groped towards a new view, an embrace of nonlinearity and the invisibility of cause-effect relations within a new framework of order: market order emerging from the random, even chaotic, behaviour of a multitude of actors (Sheehan \& Wahrman, 2015, p. 96, 104, 118).

A pivotal figure was Richard Cantillon. His own outlook could be described as Newtonian, at least inasmuch as his economic theory postulated a system of interacting and logically functioning parts that tend to equilibrium (Lewis, 2014, p. 68). The economy, accordingly, was held to be 'constantly adjusting to basic changes in population, production, tastes, and so forth,' whereby the drive of the adjustment process was 'the self-interested pursuit of profit' - a motive of such ubiquity that it takes the position in Cantillon's inquiry 'that Newton's "universal principle of attraction” (i.e. gravity) took in his' (Ekelund \& Hébert, 2013, p. 78). In applying scientific principles to economic behaviour, Cantillon has received accolades. His Essai was for William Stanley Jevons 'the first systematic treatise on economics' (Ekelund \& Hébert, 2013, p. 78). Joseph Schumpeter bracketed him together with David Hume as the first to have definitively theorized equilibrium in international trade (Dumont, 1977, p. 35), and Hayek hailed him as 'the originator of the self-adjusting price specie flow mechanism' (in Sheehan \& Wahrman, 2015, p. 131).

In his conception of the economy as a system of interconnected markets that tend to equilibrium, Cantillon anticipated Adam Smith's invisible hand. The engine and guarantor of equilibrium is the 
'free play of self-interested entrepreneurs,' as Robert Ekelund and Robert Hébert (2013, p. 79) paraphrase Cantillon; it 'keeps the system in adjustment by their conduct of "all the exchange and circulation of the State." Therefore the economy can function perfectly well without intervention in its internal mechanisms; indeed, government regulation will breed perverse effects (Maucourant, n.d.). Although crucial to establishing equilibrium, however, entrepreneurs occupy only a middling rank in Cantillon's economic hierarchy. At the top are the gentry, for as landowners the entire population depends upon them. (Land, in Cantillon's cosmology (1755/2001, p. 92), is the source of all wealth.) Particularly striking in Cantillon - and altogether neglected in the literature, except by Michael Perelman - is his theorization of the free play of market competition as the mechanism by which the social hierarchy is fixed into place. Cantillon was the first to see clearly, Perelman suggests (1983, p. 71), that market competition mediated by the price mechanism can produce essentially the same social outcome as the systems of direct command over labour found in a feudal economy; in other words, market relations function as 'an effective means of control.'

Cantillon, a stock-market speculator, was intimately involved in the 1719-20 bubbles and he wrote his famous Essai in the 1720s (Sheehan \& Wahrman, 2015, p. 130). As such, he is the key witness in Sheehan and Wahrman's case: that reverberations in society's upper echelons as the bubbles burst and order resumed formed a crucial catalyst of the entire tradition of thought that conceives of the market system in terms of spontaneous self-organization (the 'invisible hand'). It is I think a persuasive thesis. It requires some exaggeration, or at least some overlooking of the degree to which a spontaneous order paradigm had made inroads in the previous century (in the work of economists such as Dudley North) and in Mandeville's Fable of 1714. However, there is no doubt that the paradigm took wings with Cantillon, or that it reached its acme with the Scottish moralists (who drew on Cantillon), before its vulgarization in subsequent centuries by the likes of Herbert Spencer and Friedrich Hayek.

\section{Spontaneous order, from Mandeville to Spencer}

Hayek saw himself as inheritor of the tradition founded by Mandeville and the thinkers of the Scottish Enlightenment, but in several respects the positions they developed are quite unlike his. Take for example Mandeville. His Fable of the Bees is credited by Hayek (in Schneider, 1984, p. 36) as the first to display 'all the classical paradigmata of the spontaneous growth of orderly social structures: of law and morals, of language, the market and money, and also the growth of technological knowledge.' There's certainly something to this. Mandeville's recipe for social order was to put a number of selfish people together, shake it all about, and watch as an ethical society spontaneously crystallizes (Sheehan \& Wahrman, 2015, p. 6). He theorized social institutions as the products of an evolutionary process that developed as the unintended outcome of countless individual actions, and he marvelled at the marriage between demand and supply of labour in particular trades that arises 'spontaneously from the Nature of every large Society' (quoted in Hamoway, 1987, p. 9). Yet Mandeville was rather more of a mercantilist, more of a dirigiste, than Hayek allows (Petoulas, 2001, p. 100). He repeatedly compared societal harmony to the workings of a well-regulated machine. Even the most complicated clock, he reasoned, will 'work with the minimum of supervision ... once the internal mechanism is discovered and the various parts are put together.' Correspondingly, once the legal system of a society has been developed and its laws 'brought to as much Perfection, as Art and Human Wisdom can carry them, the whole Machine may be made to play of itself, with as little Skill, as is required to wind up a Clock' (Mandeville, in Petoulas, 2001, p. 96). Such analogies gesture towards the idea of spontaneous order, but in the invocations of human art and wisdom they connote, too, artifice and the 'made' order. 
More than Mandeville, it was the Scots who adumbrated a theory of spontaneously emerging social order. Moralists before they were economists, the guiding question of Hume, Smith, Adam Ferguson et al. was how to achieve virtue and social cohesion in an atomized commercial society in which the temptations of private gain lure individuals to egotism and corruption (McNally, 1988, p. 163). The institutions of modern society, they argued, are too complex to be constructed brick by brick under the command of a directing intelligence; they arise instead from the interaction of myriad individual acts - whether habitual or intentional. Hume, for example, argues that rules of property, as well as the rules and conventions of justice, money and language, evolve spontaneously, and his History of England invokes a developmental process that one commentator has dubbed 'the invisible hand of politics' (Louis Schneider quoted in Hamoway, 1987, pp. 10-13. Cf. Varoufakis, 2012). Hume is of additional relevance to my argument because he theorized the religious enthusiasm of the previous century as a prerequisite for the social framework of spontaneous order that flowered in his own. His 'Of Superstition and Enthusiasm' comes down firmly in favour of the latter. Whereas superstition 'renders men tame and abject and fits them for slavery,' enthusiasm, 'being the infirmity of bold and ambitious tempers, is naturally accompanied with a spirit of liberty' (Hume, 1967, p. 177). As such, and despite his distaste for Puritanism and his condescension toward Quakers, Hume saluted enthusiasm as a critical factor in the evolution of the spontaneously organized bourgeois habitus.

For Hume, and for Smith too, spontaneity characterizes the formation of institutions in an overarching sense - as the pattern that characterizes the social process as a whole (life evolves spontaneously from nature; property rights arise spontaneously, and on that basis the market economy spontaneously arises). Smith's focus in Wealth of Nations was economic order: the magic of the invisible hand, which weaves social order and the public good, and economic growth, from the disparate skeins of private self-interest. In Theory of Moral Sentiments (2009, p. 275), he had earlier made a not dissimilar case with the help of a different metaphor: of the legislator who is 'so enamoured with the supposed beauty of his own ideal plan of government' that he imagines 'he can arrange the different members of a great society with as much ease as the hand arranges the different pieces upon a chess-board,' failing thereby to consider that whereas 'the pieces upon the chess-board have no other principle of motion besides that which the hand impresses upon them,' in 'the great chess-board of human society, every single piece has a principle of motion of its own, altogether different from that which the legislature might chuse to impress upon it.' Continuing this complex extension of the mechanical metaphor, Smith argues in the same book (2010, Section III, Chapter 1) that society exists in harmonious self-regulation, like Newton's universe, or 'like a great immense machine, whose regular and harmonious movements produce a thousand agreeable effects.' And behind this machine lies another: human beings perceive a divinity, whose benevolence and wisdom has 'contrived and conducted the immense machine of the universe, so as at all times to produce the greatest possible quantity of happiness' (Smith, 2012, p. 237). For Smith, then, 'the ultimate ground of economic reality,' as Thorstein Veblen remarked (2018, p. 85), 'is the design of God.' The invisible hand or the market was 'attached to God's invisible arm' (Henwood, 1998).

Smith was more sympathetic than his Austrian disciple to the possibility that spontaneous order was providentially enabled, and he was more relaxed on the question of government intervention. The scale and operations of the state, Smith maintained, would grow in tandem with the rise of commercial society. (He has even been described as a structuralist development economist avant la letter (Muller, 2002, p. 76; Rostow, 1990, p. 50)). And he was famously wary of the commercial spirit and of its bearers, the mercantile and manufacturing classes. Any proposal 
emanating from these groups and claiming to be in the public interest should be treated with the utmost suspicion:

it comes from an order of men, whose interest is never exactly the same with that of the public, who have generally an interest to deceive and even to oppress the public, and who accordingly have, upon many occasions, both deceived and oppressed it. (Smith, in Davidson, 2012, p. 76)

Hence Ludwig von Mises' lament (in McNally, 1993, p. 45) - that the author of the Wealth of Nations 'could not free himself from the standards and terminology of traditional ethics that condemned as vicious man's desire to improve his own material conditions.'

This same complaint would presumably apply with greater force to Ferguson. Much as in Smith, Ferguson (1995, p. 110) identifies spontaneous social behaviour as the means by which society tends to progress. Despite the human disposition to form 'projects and schemes,' he argues, the actions of most people most of the time are governed in fact

by the circumstances in which they are placed; and seldom are turned from their way, to follow the plan of any single projector. Every step and every movement of the multitude ... are made with equal blindness to the future; and nations stumble upon establishments, which are indeed the result of human action, but not the execution of any human design.

For Ferguson, society's tendency to progress is conceived as providentially inspired yet manifested in the form of a spontaneous process consisting of myriad private acts of innumerable actors through time (Hill, 1997, p. 678). As the central engine of progress he identifies the market system, and yet he was plagued by the tensions between commerce and virtue. His Essay on the History of Civil Society abounds with reservations about the 'polished' society of expanding commerce exhibited by England, which paradoxically, he held, contained the seeds of its own destruction (Hill, 1997, p. 681; Hirschman, 1977/1997, p. 107; Wood, 2012, p. 283, 311). If for Smith the accent is on the 'spontaneously cohesive' structures of commercial society, Ferguson is more sceptical (Eagleton, 1990, p. 37). In his reading, the commercial age, while a natural product of the workings of spontaneous order, had brought luxury, egotism, decadence and a weakening of the civic spirit, all of which bring the danger of social collapse (Hill, 1997, p. 681).

From the Scottish moralists onward, the theme of spontaneous order can be traced through left Smithians such as Tom Paine, for whom the self-organizing resilience of the social order allows for political experiments and ruptures, and through right Smithians (or Humeans) such as Edmund Burke, for whom the evolution of political order, being gradual, planless and the product of a multitude of human customs and conventions, is necessarily conservative; ergo its laws and institutions should not be rashly tampered with (Sheehan \& Wahrman, 2015, p. 279). From Burke, through Herbert Spencer and then Hayek, the concept assumed an increasingly vulgar stamp. In Spencer's case the vulgarity consisted in his bolting the idea of spontaneous order onto a simple dichotomy of 'militant' versus 'industrial' society. In a polemical simplification of the spontaneous order thesis, Spencer bundles the policy regime that Smith opposed, mercantilism, together with all pre-commercial stages of society, in opposition to commercial (in Spencer's lexicon 'industrial') society. Primitive militant societies are characterized by command and control, with governments or chieftains calling the shots; the result is economic backwardness, social tension and international conflict. In industrial society, by contrast, individuals work for one another, motivated by a blend of egotism and sympathy (Bowler, 1989; Spencer, $1884 / 92 / 1969$, p. 134). The mechanism that enables this felicitous outcome is the market. It embodies the principle of evolutionary spontaneous order, which permits free enterprise and individual initiative to flourish, with peace, prosperity and progress as the civilizational consequences. 


\section{Michael Polanyi and Friedrich von Hayek}

In the twentieth century, Spencer's dichotomy was adapted and developed. A milestone arrived in 1948 with Michael Polanyi's essay on 'Planning and Spontaneous Order.' The distinction Polanyi made was between spontaneous and corporate orders. The former is a horizontal arrangement in which each individual decides how to act, adjusting their actions to the outcomes of others, allowing the system to evolve through agents' decisions and mutual adaptation. The latter, exemplified by a ship's crew, a firm, or an army, exhibits a pyramidal structure, with descending lines of authority. Such organizations are commanded by an executive, which plans strategy. Typically, the plan is guided by a single overarching goal. The two types, Polanyi notes, are not radically separate. Market actors, for example, interact on their own initiative but are subject to laws laid down by government (Jacobs, 2000, pp. 57-59).

Like Michael Polanyi (and indeed Karl Polanyi), Hayek's economic philosophy was informed by ethical individualism. A 'free society,' he held (1960/2006, p. 63), requires that 'its members regard it as right that each individual occupy the position that results from his action and accept it as due to his own action.' In turn, this necessitates a system of absolute private property. The exclusive right of owners to determine the use of their property encourages individual responsibility, enabling each to make full use of his knowledge and possessions in the interests of himself and the wider community (Hayek, 1936/2009, p. 20). On this basis, a spontaneous, 'endogenously' grown, evolutionary order or cosmos - arises, featuring unintended yet coherent networks of relations through which actors pursue their heterogenous aims regulated only by common procedural rules. It is defined in opposition to taxis: 'exogenously' constructed, artificial orders, where purposive organizations such as governments, families, farms and corporations seek to realize substantive collective goals (Jacobs, 2000, p. 51).

For Hayek, as for the Scottish moralists, commercial society brings about a civilized order - an order, in other words, that facilitates social progress. For him it is 'civilization,' with Western market society at the pinnacle, that 'distinguishes man from beast' - far more than language, culture, tool use, or the many other human qualities that flourish in 'pre-civilized' societies (Hayek, 1960/2006, p. 37). In making this argument, Hayek is at pains to detach spontaneity from its associations with 'natural instinct.' Primitive peoples, whose ethical systems are geared to norms of 'solidarity' and 'altruism,' are in his cosmology closer to beasts, for their social organization consists of 'made' orders: they are 'guided by innate instincts to pursue common perceived goals' (Hayek, in Papaioannou, 2012, p. 103). History's 'vanguard' societies, by contrast, are those that pioneered the market economy and imposed it on the rest. They learned to embrace the open society, with its abstract rules, and that for Hayek is the road to civilization and progress.

What, Hayek asks next, is progress? It is above all the growth of knowledge, and the accumulation of capital. 'The market system,' he argues in Law, Legislation and Liberty (2012, p. 275), is the spontaneous, evolutionary, progressive order par excellence. It

leads not only to the creation of an order, but also to a great increase of the return which men receive from their efforts. ... It is a wealth-creating game, that is, one that leads to an increase of the stream of goods and of the prospects of all participants to satisfy their needs.

And how to ensure that economic growth continues? One must encourage the rich - the 'vanguard' of civilization - by ramping up inequality, for their gains will eventually 'become available to the rest'; indeed, all rational hopes 'for the reduction of present misery and poverty rest on this expectation' (Hayek, 1960/2006, p. 46). Here Hayek's position may usefully be compared with that of Smith and Ferguson. Not unlike Smith, for Hayek economic growth figures as a key index of social 
progress, but whereas Smith nurtured the (illusory) hope that over time capitalist growth would equalize incomes, Hayek celebrates its tendencies to income polarization. And whereas Ferguson worried about the corrosive impact of commerce and self-interest on public virtue, when Hayek writes about virtue, he tends to praise the market for producing distinctly commercial virtues.

Hayek's schema has been subjected to critique from various angles. One is identified by the political theorist William Connolly. Connolly shares Hayek's fascination with sophisticated and multifarious self-organizing systems in the natural world and in the market economy. But the market economy, he points out, is not the only social system 'that displays moments of creative spontaneity and differential degrees of self-organizing power.' These creative traits are found in other spheres of social life in which Hayek displayed negligible interest, notably 'spontaneous social movements.' A corollary of this blind spot is that Hayek tended to exaggerate 'the self-organizing power of markets by implicitly deflating the self-organizing powers and creative capacity' of other systems - certainly social movements, and also politics. These, Connolly proposes (2013, p. 66), should be included 'within the domain of creative spontaneity' as opposed to the Hayekian 'desire to contain democratic politics.'

A second critical observation is that Hayek maps the cosmos/taxis couplet onto a set of dichotomies: endogenously grown vs. exogenously designed, evolutionary rationalism vs constructivist rationalism, market vs planning, freedom vs despotism, individualism vs collectivism, capitalism vs socialism, liberalism vs totalitarianism, and so on. With this move, a dichotomy with suggestive uses as a social-scientific model becomes a manifesto, a credo that counterposes coercive, lumbering and inevitably over-reaching statist centralism to the realm of individual initiative, private enterprise, the spontaneously evolving and smoothly self-adjusting market cosmos, and the rule of law (which Hayek believes to be the spontaneously achieved corpus of rules, which, being abstract and impartially applied, are antithetical to coercion and belong instead in the realm of freedom (Connolly, 2013, p. 31; Hayek, 1960/2006). Of course, Hayek (and Michael Polanyi) recognize that spontaneously ordered systems in practice include organized corporate parts - just as firms, in a formulation of Dennis Robertson, exist as islands of conscious power in an ocean of unconscious cooperation, like lumps of butter coagulating in a pail of buttermilk.' And they accept that actions in a corporate order are not necessarily merely responses to the diktat of one's superordinates. However, they, and Hayek in particular, etch a sharp line between the two types of order, such that an entity must be of one type or the other. They recognize interaction but exclude fusion, or hybrids. It is a Manichean procedure in that, in the worldview it defines, order exists either as cosmos or taxis (Petoulas, 2001, p. 12). It is a distinction, moreover, that cannot bear much weight because, as Timothy Sandefur has shown (2009), the difference between spontaneous and constructed orders tends to collapse on close examination. What some perceive to be the application of a spontaneously evolved rule appears to others as constructivist intervention. In The Road to Serfdom, Hayek (1944/ 1986, p. 71) reveals that his attitude 'toward society is like that of the gardener who tends a plant.' What this elides, Sandefur argues (2009), is that the gardener stands outside the garden 'with an exogenous idea of how it ought to look, and he rationally constructs it, prudently allowing plants to grow in some ways and pruning back others.' In Hayek's understanding (1960/2006, p. 141), the spontaneous order requires a 'lawgiver' whose task it is 'induce' the establishment of order by creating conditions 'in which an orderly arrangement can establish and ever renew itself.' The market system relies on a strong state with a deliberately designed constitution, and to that extent it is itself constructivist.

In Hayek's dichotomy, then, there is little scope for seeing an order as 'buttermilk' from one vantage point, 'butter' from another. Consider the signing of a wage contract: a spontaneously achieved 
agreement between private citizens and a document of corporate serfdom. Or consider the politburo of the GDR. From one line of sight its decrees were a classic case of 'constructing order'; from another, it was a participating actor within, and buffeted by, a multitude of 'spontaneous' forces geo-economic, balance of power, consumer industrial struggle, and so on. Moreover, Hayek's schema obscures the tendency of the market order to permit monopoly logics and the transmutation of market success into economic power - in which corporations 'can first enact initiatives on their own in the market and then use funds, lobbying power, campaign contributions, collusion, and bribery to consolidate those advantages through the state' (Connolly, 2013, p. 62). Such phenomena cannot be separated out from the market order and reduced to policy and politics - the 'made order.'

Hayek regarded his thoughts on spontaneous order as a continuation in more sophisticated form of the Smith-Hume lineage, but as suggested above, his position was in several respects blunter and cruder. And whereas the Austrian placed enormous emphasis on trial and error in competitive conditions and independently of human understanding as the means by which institutions develop and adapt, with the Scots there is also a pronounced emphasis, in their explanations of the origins and evolution of private property and political institutions, on rational deliberation, intentional experimentation and the active comprehension of actors (Petoulas, 2001, p. 137). In their approach, a good deal of 'selection' is not trial-and-error but deliberate, and led above all by virtuous public-spirited gentlemen. As noted above, articulations of market and command are largely elided in Hayek's work. Throughout, Hayek overstates the element of spontaneity in the evolution of the market order, and understates the deliberate construction work undertaken by policymakers and officials. Of this, few were more acutely aware than Karl Polanyi.

\section{Karl Polanyi: against 'spontaneous spontaneity'}

The political philosophies of Polanyi and Hayek could hardly have been more different. Polanyi was a socialist. But how did this affect his approach to spontaneity? In the era in which he came of age, the term was much used in the socialist vocabulary, and with a polysemy not unlike that discussed above. For example, in his infamous (because editorially bowdlerized) Introduction to Marx's Class Struggles in France, Friedrich Engels (1895) brings spontaneity into play in a positivist way, in an allusion to the German workers' movement's inevitable tendency to progressive evolution and ultimate triumph: 'Its growth proceeds as spontaneously, as steadily, as irresistibly, and at the same time as tranquilly as a natural process.' For a later generation of Marxists, Rosa Luxemburg for example, spontaneity was more likely to be used to refer to the mass activism and political learning processes of working people: the processes through which social movements arise and through which actors gain consciousness of their collective self-identity, their interests, and so on (Borch, 2012, p. 90). The young Polanyi was no follower of Luxemburg; he was drawn rather to her arch-antagonist on the 'revisionist' right of social democracy, Eduard Bernstein, in whose view history was evolving inevitably toward ever greater democracy. It was in a Bernsteinian critique of Karl Kautsky that we find Polanyi's first use of 'spontaneous.' Kautsky, he charges, 'is unable to understand the new forms of democracy that are welling up from the spontaneous life of labour' (Polanyi, 2016).

It was in later life, in the 1940s, that 'spontaneity' entered Polanyi's work in a more systematic way, most notably in an essay on Rousseau - a philosopher who is to Polanyi as Hume is to Hayek (Tamás, 2006). Rousseau (1979) partook of a Romantic sensibility that counterposed civilization to nature, and the external law-governed motions of the planets to the internal 'spontaneous' movements of living creatures. The Genevan thinker's critique of modern civilization - cruel, frenzied, competitive and harsh, in opposition to primitive gentleness, idleness, abundance and 
spontaneity - was echoed by Polanyi (1947/1968, pp. 59-60) in his critique of 'industrial civilization, with its paralyzing division of labour, standardization of life, supremacy of mechanism over organism, and organization over spontaneity.'

Polanyi deployed the concept of spontaneity within a framework that is broadly Romantic but within the standard Enlightenment parameters: spontaneity must be guided. This can be seen in Polanyi's essay on Rousseau. It begins with Rousseau's quandary over freedom, which Polanyi phrases as the conflicting imperatives of individualism and totalitarianism. The totalitarian element 'derives from the naturalistic law of survival' (every human society 'behaves in such a fashion as to ensure its survival, irrespective of the will of the individuals composing it') while its individualistic counterpart 'derives from the normative principle of natural law' (every free society 'bases its behaviour on the wills of the persons constituting it') (Polanyi, n.d.). The Rousseauian volonté générale is, then, in a sense 'simply the principle of survival (Polanyi, 1943).' But if that is the case, how is freedom possible? Polanyi did not suppose that Rousseau had resolved the paradox but he had at least pointed toward the solution. Crucially, it was Rousseau who first discovered the reality of society. Through social bonds (or the 'social contract') each citizen is pledged to support her fellows, and receives 'the same pledge from all, in exchange.' In recognizing political society as real, 'i.e. subject to laws of nature and morality,' Rousseau had demonstrated the limits to 'illusions and wishful thinking,' in particular the belief that 'freedom is a principle on which society can be safely based and that individuals will spontaneously conform to all demands.' Through these insights, Rousseau had discovered the path toward freedom in modern, 'complex' society, with freedom understood as rational self-direction, a path that can only be realized through the collective control of the common life, a reconciling of individual freedom with the reality of society. He had demonstrated, in other words, that there exists 'no "best form of government"; no spontaneous spontaneity, no natural freedom which can make a society survive.' In order to reconcile the dictates of survival and freedom, the dispositions of the people, enabled by processes of collective self-education and moral discipline, must be 'such that they will spontaneously work their institutions in such a way as to allow society to survive' (Polanyi, n.d.).

Like Rousseau, Polanyi (1955) found lessons for modernity in societies of antiquity - for example Old Assyria, where economic behaviour, in his interpretation, was regulated simply by law, which ensured that there was

no bureaucracy, no administration, no command, no shifting of responsibility: instead the organization of trade is free, spontaneous, undirected but within an institutional frame which leaves it to the individual to act at will as long as he keeps to the law.

This sort of mediated spontaneity was quite unlike the modern market society that had been called into being by the ideologues of spontaneous economic order. In The Great Transformation, Polanyi takes the Smith-Hayek lineage to task for its veneration of spontaneous progress. 'Nowhere,' he thunders,

has liberal philosophy failed so conspicuously as in its understanding of the problem of change. Fired by an emotional faith in spontaneity, the common-sense attitude toward change was discarded in favor of a mystical readiness to accept the social consequences of economic improvement, whatever they might be. ... A blind faith in spontaneous progress had taken hold of people's minds, and with the fanaticism of sectarians the most enlightened pressed forward for boundless and unregulated change in society. The effects on the lives of the people were awful beyond description.

The belief in spontaneous progress, he continues, had blotted out

the role of government in economic life. This role consists often in altering the rate of change, speeding it up or slowing it down as the case may be; if we believe that rate to be unalterable-or even worse, if we 
deem it a sacrilege to interfere with it-then, of course, no room is left for intervention. (Polanyi, 1944/ 2001 , p. 35, 39, 79)

In his defence of radical state intervention and national planning, Polanyi and Hayek's views were antithetical, but on certain matters of relevance to this article they were close. Polanyi found inspiration in the economics of the Austrian school, including Böhm-Bawerk, Schumpeter, and above all its founding father, Carl Menger (of whom Hayek was also a great admirer, in particular for his theorization of the spontaneous generation of social institutions). Polanyi defined the capitalist market economy, as Alexander Ebner (2011, p. 31) points out, in the Austrian manner: 'almost exclusively as a domain of exchange, contract and profit.' He referred to it as the 'self-regulating market,' the 'market economy' or the 'market system' - terms that, as J. K. Galbraith (2004, pp. 6-8) has argued, distance contemporary society from the unsavoury associations of capitalist power. With Hayek, Polanyi identified the late nineteenth century as the juncture at which liberalism's political, economic and intellectual decline commenced, and, with Hayek, he viewed the interwar corporatist shift in economic policymaking as propitious to, if not direct evidence of, a transition to socialism. This was a leitmotif in The Great Transformation and in Hayek's contemporaneous The Road to Serfdom, which suspected the hydra of socialism in almost every act of planning or direct economic intervention. Both books, Hüseyin Özel (n.d.) observes, use 'similar models to explain the working of capitalism.' Despite differences of terminology, they analyse capitalism's institutional structure in much the same way.

This combination of analytical similarity and normative antithesis is strikingly apparent in respect of the theorization of spontaneous/constructed orders. Here, Polanyi's position is the very mirror of Hayek's. For the Austrian, macro-economic steering and overambitious social policy represent the trespass of taxis onto the terrain of cosmos. The Road to Serfdom (1944/1986, p. 14) warns against those who advocate restrictions on markets, whether in the form of 'socialism in its more radical form or merely "organisation" or "planning” of a less radical kind.' For the Hungarian, the collectivist countermovement arises spontaneously, in resistance to the artificial market machine. Even government intervention, the 'legislative spearhead' of the countermovement 'as it developed in the half century following 1860, turned out to be spontaneous, undirected by opinion, and actuated by a purely pragmatic spirit' (Polanyi, 1944/2001, p. 147).

Like Polanyi, the sharp line Hayek draws is between the liberal market economy (or 'extended order') and any form of regulated society (or 'tribal order'), but for the Austrian the polarity is reversed: a regulated society is anathema, liberal capitalism the ideal. If nineteenth-century liberalism suffered from a single shortcoming it was that its triumphant progress had encouraged hubris - a perfectionist, even utopian, overreach - that excited the romantic instincts of its enemies, socialism and fascism, which thereupon joined it in battle. In this way, it may well have been

that the very success of liberalism became the cause of its decline. Because of the success already achieved man became increasingly unwilling to tolerate the evils still with him, which now appeared both unbearable and unnecessary. (Hayek, 1944/1986, p. 16)

For Hayek, the utopian aspect is not intrinsic to liberalism but is an irrational and unjustifiable leap beyond it. For Polanyi, by contrast, that element is irrational but also inherent: economic liberalism is necessarily utopian for it brings into being an artificial institutional assemblage against which society, understandably and rationally, reacts. The 'disruptive strains' that emerged around the time of his birth and which then led to the dismantling of liberal institutions in those interwar decades in which the ideas of The Great Transformation were germinating were the dragons' teeth sown, inevitably and as a product of its nature, by classical liberalism itself. In this way, Polanyi inverts a wellrehearsed right-wing charge against socialism: that it represents a utopian exercise in social 
engineering, inhuman in its suppression of catallactic spontaneity. In Polanyi's schema the tables are turned: economic liberals are the utopian extremists; their opponents merely the bearers of the inevitable and spontaneous reaction of social protection.

\section{Conclusion}

'Spontaneity' has come to occupy a privileged niche in social-theoretical vocabulary and little wonder. A feel-good word, when applied to bourgeois society spontaneous order connotes freedom, the demos, and the natural, as contrasted with terms ('market anarchy,' 'organized capitalism,' etc.) that evoke disorder, or the whip, and the chain of command. In Hayekian theory the emphasis is on webs of transactions through which individuals negotiate their business affairs, responding and adapting all the while to the new information provided by market prices (Petoulas, 2001, p. 37). This presumes that market-mediated transactions produce order rather than 'spontaneous disorder' - with its implication of the need for interventionist policies (Tieben, 2012). And it elides the 'abode of production' in which labour is subject to despotism. So for example when Hayekians describe Facebook as a 'superb example of Spontaneous Order' (Easterly, 2011), we can be sure that the owners and designers, not to mention the unslakeable thirst for biopolitical power, are discreetly shaded from view.

In contradistinction to Hayek, Karl Polanyi proposed that the market system is an artificial construct, and whereas Hayek, following Ricardo, postulated that if the state seeks to intrude arbitrarily into the market mechanism anonymous social forces will resist, he proposed the converse: the foisting of the market mechanism upon society will elicit a protective response, or 'countermovement.' The 'laissez-faire economy,' in Polanyi's words, was 'the product of deliberate state action.' In this, he was voicing an argument shared by other interwar socialists. Antonio Gramsci (1971, p. 160), for example, saw the self-regulating market as politically engineered:

a form of State 'regulation,' introduced and maintained by legislative and coercive means; ... a deliberate policy, conscious of its own ends, and not the spontaneous, automatic expression of economic facts.... Laissez-faire liberalism is a political programme designed to ... change the economic program of the state itself.

But what is peculiar to Polanyi is that he counterposed (artificial) liberal economics to the 'subsequent restrictions on it' which 'started in a spontaneous way.' Where the market system was socially engineered, society 'unconsciously resisted any attempt at being made into a mere appendage of the market' (Polanyi, 1944/2001, p. 141). The myriad impulses behind collectivist interventions, in short, had arisen spontaneously in resistance to the market machine. Polanyi's 'counter-movement' is society's spontaneous rebuke to the 'made' market order.

In his reaction against liberal apologetics that contrast the market economy as spontaneous and functional with the constructedness and dysfunctionality of state intervention, Polanyi (1944/2001, p. 141) reversed the polarity, emphasizing the 'extreme artificiality' of the market system. The historian Mohammad Nafissi (2005, p. 168) has put the point pithily, in a paraphrase of Polanyi:

Market society had to collapse not so much because its opponents appeared to have gained the upper hand in the 1930s, but because it violated human nature which in turn explains why its opponents had gained the upper hand.

Polanyi's conception of human nature, I would add, was Christian-inflected. In this regard, 'providence', in the broad sense that a divine force exists conducive to social harmony, is present in his outlook in a manner that the Scottish moralists would have recognized, but not Hayek, who seeks to obscure the centrality of providence to the tradition he seeks to inherit. 
Polanyi's dichotomy of 'artificial liberalism' and 'natural protectionism' in one sense echoes Hayek's. Both theorists regarded the modern market system as a clear departure from earlier economic arrangements that had expressed the communitarian instincts of human beings. In another sense it is antithetical to Hayek. In Hayek's dichotomy, the positive attributes are heavily on the liberal-market side; in Polanyi's the weight is on the statist and protectionist side. Both thinkers play down relations of exploitation. In Hayek's case (1960/2006) this is achieved by constructing a freedom-coercion dichotomy in which coercion is identified strictly with the direct application of state power and by way of his justification of social inequality in market society. In Polanyi's case it is achieved by understating the oppressive and exploitative relations in 'redistributive' societies, from Mesopotamia to Dahomey to the Soviet Union and, in general, through a neglect of conflict, competition and power relations. The weight of explanation invariably falls upon the pattern of economic integration and rarely if ever upon the exercise of control over productive property and the systematic relationships of inclusion and exclusion that flow from it. In creating these blind spots, the concepts of spontaneity and spontaneous order play an active part. For Hayek, the market system is defined as a manifestation of spontaneous order in which individuals are able to flourish in a coercion-free realm. For Polanyi, a Romantic-tinged concept of spontaneity affirms the thesis that the protectionist countermovement is a 'natural' response by 'society' to the depredations of the market system, allowing relations of power to remain under-specified.

\section{Acknowledgements}

This article was first presented at the Research Colloquium 'Crowd Dynamics and Financial Markets,' Copenhagen Business School, October 2015. It also draws on materials I presented at the workshop 'Questioning the Utopian Springs of Market Economy,' University of Sydney/Australia (15-16 August 2014). I thank the participants at both events, and the anonymous reviewers, for their comments.

\section{Disclosure statement}

No potential conflict of interest was reported by the author.

\section{Notes on contributor}

Gareth Dale teaches politics at Brunel University. He has written and edited books on migrant labour, the GDR and Eastern Europe, Karl Polanyi, and green growth. His current research is on the 'growth paradigm.'

\section{ORCID}

Gareth Dale (D) http://orcid.org/0000-0003-4991-6063

\section{References}

Borch, C. (2012). The politics of crowds: An alternative history of sociology. Cambridge: Cambridge University Press.

Bowler, P. (1989). The invention of progress: The Victorians and the past. Cambridge: Blackwell.

Branch, L. (2009). Rituals of spontaneity: Sentiment and secularism from free prayer to Wordsworth. Waco: Baylor University Press.

Cantillon, R. (1755/2001). Essay on the nature of commerce in general. Somerset: Transaction. 
Connolly, W. (2013). The fragility of things: Self-organizing processes, neoliberal fantasies, and democratic activism. Crowhurst: Duke University Press.

Davidson, N. (2012). How revolutionary were the bourgeois revolutions? Chicago: Haymarket.

Dumont, L. (1977). From Mandeville to Marx: Genesis and triumph of economic ideology. Chicago: The University of Chicago Press.

Durant, W., \& Durant, A. (1963). The story of civilization: The age of Louis XIV, 1648-1715. New York: Simon and Schuster.

Eagleton, T. (1990). The ideology of the aesthetic. Cambridge: Blackwell.

Easterly, W. (2011). Complexity, spontaneous order, blah, blah, blah ... and wow. Retrieved from http:// aidwatchers.com/2011/01/complexity-spontaneous-order-blah-blah-blah-and-wow/

Ebner, A. (2011). Transnational markets and the Polanyi problem. In C. Joerges \& J. Falke (Eds.), Karl Polanyi, globalisation and the potential of law in transnational markets. Oxford: Hart.

Ekelund, R., \& Hébert, R. (2013). A history of economic theory and method: Sixth edition. Long Grove: Waveland Press.

Engels, F. (1895). Introduction. Retrieved from www.marxists.org/archive/marx/works/1850/class-strugglesfrance/intro.htm

Ferguson, A. (1995). An essay on the history of civil society. Cambridge: Cambridge University Press.

Foucault, M. (2008). The birth of biopolitics: Lectures at the Collège de France, 1978-79. Basingstoke: Palgrave.

Galbraith, J. K. (2004). The economics of innocent fraud. Boston: Houghton Mifflin.

Ginzburg, C. (1976). The Cheese and the Worms: The cosmos of a sixteenth-century miller. Harmondsworth: Penguin.

Gramsci, A. (1971). Selections from the prison notebooks. London: Lawrence \& Wishart.

Hamoway, R. (1987). The Scottish enlightenment and the theory of spontaneous order. Carbondale: Southern Illinois University Press.

Hayek, F. (1936/2009). Individualism and economic order. Auburn: Ludwig von Mises Institute.

Hayek, F. (1944/1986). The road to serfdom. London: ARK Paperbacks.

Hayek, F. (1960/2006). The constitution of liberty. London: Routledge.

Hayek, F. (2012). Law, legislation and liberty: A new statement of the liberal principles of justice and political economy. London: Routledge.

Henwood, D. (1998). Wall street. London: Verso.

Hill, L. (1997). Adam ferguson and the paradox of progress and decline. History of Political Thought, XVIII(4), 677-706.

Hirschman, A. (1977/1997). The passions and the interests: Political arguments for capitalism before its triumph. Princeton: Princeton University Press.

Hume, D. (1967). Of superstition and enthusiasm. In L. Schneider (Ed.), The Scottish moralists on human nature and society (pp. 170-183). Chicago: University of Chicago Press.

Jacobs, S. (2000). Spontaneous order: Michael Polanyi and Friedrich Hayek. Critical Review of International Social and Political Philosophy, 3(4), 49-67.

Knafo, S. (2013). The making of modern finance: Liberal governance and the gold standard. London: Routledge. Leibnitz, G. (1692/2010). The shorter Leibniz texts: A collection of new translations. London: Bloomsbury.

Lewis, C. (2014). A coincidence of wants: The novel and neoclassical economics. London: Routledge.

Losonsky, M. (2001). Enlightenment and action from Descartes to Kant: Passionate thought. Cambridge: Cambridge University Press.

Maucourant, J. (n.d.). The ambiguous birth of political economy - a discussion of the work of Montchrestien and Cantillon. Manuscript in possession of the author.

McNally, D. (1988). Political economy and the rise of capitalism: A reinterpretation. Berkeley: University of California Press.

McNally, D. (1993). Against the market: Political economy, market socialism and the Marxist critique. London: Verso. Muller, J. (2002). The mind and the market: Capitalism in modern European thought. New York: Alfred Knopf.

Nafissi, M. (2005). Ancient Athens and modern ideology; value, theory and evidence in historical sciences. London: Institute of Classical Studies.

Özel, H. (n.d.). The road to serfdom in the light of the great transformation: A comparison on the basis of unintended consequences. Retrieved from http://yunus.hacettepe.edu.tr/ ozel/HayekvsPolanyi.pdf 
Papaioannou, T. (2012). Reading Hayek in the 21st century: A critical inquiry into his political thought. Basingstoke: Palgrave.

Perelman, M. (1983). Classical political economy, primitive accumulation and the social division of labor. Totowa: Rowman \& Allanheld.

Petoulas, C. (2001). Hayek's liberalism and its origins: His idea of spontaneous order and the Scottish enlightenment. London: Routledge.

Polanyi, K. (1943). To Misi, 29 September, Michael Polanyi Papers, University of Chicago, Box 17, Folder 10. Polanyi, K. (1944/2001). The great transformation. Boston: Beacon Press.

Polanyi, K. (1947/1968). Our obsolete market mentality. In G. Dalton (Ed.), Primitive, archaic and modern economies: Essays of Karl Polanyi (pp. 57-73). Boston: Beacon Press.

Polanyi, K. (1955). KPA-49-4, Letter to John, 5 January.

Polanyi, K. (2016). Karl Kautsky and democracy. In G. Dale (Ed.), Karl Polanyi: The Hungarian writings (pp. 114-117). Manchester: Manchester University Press.

Polanyi, K. (n.d.). Polanyi, 'Jean Jacques Rousseau,' Karl Polanyi Archive, Concordia University, Box 18, Folder 24.

Rostow, W. (1990). Theorists of economic growth from David Hume to the present. Oxford: Oxford University Press.

Rousseau, J.-J. (1979). Emile. New York: Basic Books.

Sandefur, T. (2009). Some problems with spontaneous order. The Independent Review, 14(1), 5-25.

Schneider, L. (1984). The grammar of social relations: The major essays of Louis Schneider. Somerset: Transaction.

Sgarbi, M. (2012). Kant on spontaneity. London: Continuum.

Sheehan, J., \& Wahrman, D. (2015). Invisible hands: Self-organization and the eighteenth century. Chicago: University of Chicago Press.

Smith, A. (2009). Theory of moral sentiments. Harmondsworth: Penguin.

Smith, A. (2010). Theory of moral sentiments. New York: Harriman House Limited, Section III, Chapter 1.

Smith, A. (2012). The theory of moral sentiments. North Chelmsford: Courier Corporation.

Spencer, H. (1884/92/1969). The man versus the state. Harmondsworth: Penguin.

Tamás, G. M. (2006). Telling the truth about class. Retrieved from www.gerlo.hu/kommunizmus-vita/tgm/ telling_the_truth_about_class.pdf

Tieben, B. (2012). The concept of equilibrium in different economic traditions: An historical investigation. Cheltenham: Edward Elgar.

Varoufakis, Y. (2012). Why valve? Or, what do we need corporations for and how does valve's management structure fit into today's corporate world? Retrieved from http://blogs.valvesoftware.com/economics/why-valve-or-whatdo-we-need-corporations-for-and-how-does-valves-management-structure-fit-into-todays-corporate-world/

Veblen, T. (2018). The place of science in modern civilization. London: Books on Demand.

Weber, M. (1905/1992). The protestant ethic and the spirit of capitalism. London: Routledge.

Wennerlind, C. (2011). Casualties of credit: The English financial revolution, 1620-1720. Cambridge: Harvard University Press.

Wood, E. (2012). Liberty and property: A social history of western political thought from renaissance to enlightenment. London: Verso.

Ziman, J. (1991). Reliable knowledge: An exploration of the grounds for belief in science. Cambridge: Cambridge University Press. 